\title{
Management of Hypertension in the Elderly by Modern Methods
}

\author{
Sorina Maria Aurelian,2, Ruxandra Dascalescu ${ }^{1,2}$, Andreea Zamfirescu ${ }^{1,2}$, Ana Capisizu $^{1,2}$
}

\begin{abstract}
Introduction: Monitoring of antihypertensive therapy is a challenge for any patient, but especially for the elderly. Management of high blood pressure in the elderly raised many questions about lowering blood pressure and the risk of falls. Methods: A cross-sectional, observational study of 150 patients; mean-age $74.68 \pm 7.49$ years with antihypertensive therapy. Daily blood pressure and hemodynamic modulators (volemia, inotropism, chronotropism) were measured using thoracic electrical impedance (TEB-System HOTMAN ${ }^{\circledR}$ ). The evaluated haemodynamic profile was correlated with each administered antihypertensive drug/class. Results: $79.5 \%$ of patients were therapeutically controlled; $93.1 \%$ had at least one modified hemodynamic modulator ( $<0.0001)$. Distribution of antihypertensive drugs: Indapamidum (85.7\%), Carvedilolum (42.9\%), Perindoprilum (36.7\%), Candesartanum (16.3\%). The correlation between hemodynamic and antihypertensive modulators: $72.7 \%$ had hypervolemia; only $29.7 \%$ were treated with diuretics, with statistically significant results $[x 2=2.79 ; p=0.09]$; patients treated with ACEI/ARBs had hypoinotropism (52.3\%)/hyperinotropism (40.9\%). 54.5\% of patients with beta-blockers had statistically significant results for hypocronotropy $[\times 2=11.35 ; p=0.001]$. Conclusions: Hemodynamic profile helps identify the causes of uncontrolled hypertension with different classes of antihypertensive drugs. The effect of beta blockers on chronotropism is depending on age and type (selective/non-selective). The effect of thiazide diuretics, associated with a high risk of falls in the elderly, shows the presence of hypervolemia in a small rate, which implies individualized treatment at the elderly, depending on comorbidities and drug interactions.
\end{abstract}

Keywords: hypertension, hemodynamic status, elderly

\section{Rezumat}

Introducere: Monitorizarea terapiei antihipertensive reprezinta o provocare pentru orice pacient, dar mai ales pentru vârstnic. Managementul hipertensiunii arteriale la vârstnici a ridicat numeroase întrebări privind scăderea tensiunii arteriale și riscul de cădere. Material și metode: Este un studiu observațional, transversal, pe 150 de pacienți cu

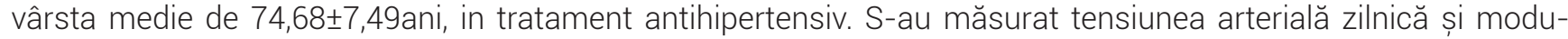
latorii hemodinamici (volemia, inotropismul, cronotropismul) utilizând impedanța electrică toracică (TEB-System HOTMAN ${ }^{\circledR}$ ). Profilul hemodinamic determinat a fost corelat cu fiecare medicament/clasa de antihipertensiv administrat. Rezultate: 79,5\%dintre pacienți au fost controlați terapeutic; 93,1\% au avut cel puțin un modulator hemodinamic modificat $(p<0,0001)$. Distribuția medicamentelor antihipertensive: Indapamidum $(85,7 \%)$, Carvedilolum (42,9\%), Perindoprilum (36,7\%), Candesartanum (16,3\%). Corelația dintre modulatorii hemodinamici și antihipertensive: $72,7 \%$ au avut hipervolemie, din care doar $29,7 \%$ au fost tratați cu diuretice, au rezultate semnificativ statistice $[\times 2=2,79 ; p=0,09]$; pacienți în tratament cu IECA/BRA prezinta hipoinotropism (52,3\%)/hiperinotropism (40,9\%). $54,5 \%$ dintre pacienții cu beta-blocanți au avut rezultate semnificativ statistic pentru hipocronotropism [x2=11,35; $p=0,001]$. Concluzii: Profilul hemodinamic ajută la identificarea cauzelor hipertensiunii necontrolate cu diferite clase

${ }^{1}$ "Carol Davila" University of Medicine and Pharmacy, Bucharest, Romania

2 "Sf. Luca" Chronic Disease Hospital, Bucharest, Romania
Corresponding author.

Sorina Maria Aurelian, Sos. Berceni, no 12, $1^{\text {st }}$ floor, $4^{\text {th }}$ District, Bucharest, Romania.

E-mail: sorinamaria.aurelian@gmail.com 
de medicamente antihipertensive. Efectul beta-blocantelor asupra cronotropismului depinde de vârstă și de tipul acestora (selectiv/neselectiv). Efectul diureticelor tiazidice, asociat cu un risc crescut de cădere la vârstnici, arată prezența hipervolemiei într-o rată mică, ceea ce implică tratament individualizat la vârstnici, în funcție de comorbidități și interacțiuni medicamentoase.

Cuvinte cheie: hipertensiune, status hemodinamic, vârstnici

\section{INTRODUCTION}

An increasing public health concern is the hypertension in the elderly (above the age of 65 years) ${ }^{1}$, which is under-recognized as a major contributor to premature disability and institutionalization ${ }^{2}$. Numerical increase in older people and consequently the consumption of drugs, associated with morpho-functional changes of the old body, bring the elderly in relationship with drugs in different position than young adults. $\mathrm{A}$ individual pharmaco-geriatrics are a necessity ${ }^{3-5}$ especially that are a multitude of medications such as cardiovascular, gastrointestinal, central nervous system, analgesics, and vitamin agents ${ }^{6,7}$.

Management of hypertension in the elderly raises particular challenges and has raised questions about the relationship between blood pressure (BP) lowering and risk of falls ${ }^{8}$ knows that in the fifth and sixth decade of life, systolic blood pressure(SBP) and diastolic blood pressure (DBP) increase linearly, after SBP continues to rise while DBP gradually decreases ${ }^{9}$.

Blood pressure is not under control in many cases The goal blood pressure $(<140 / 90 \mathrm{mmHg})$ achieved only in $57 \%$ cases and impedance cardiography is a better management than standard care in uncontrolled patients with 1-3 antihypertensive medications $s^{10,11}$. Recent literature emphasizes the importance of identifying the hemodynamic profile of hypertensive patients as a valuable tool for the management of hypertension ${ }^{12-14}$.

We want to identify the hemodynamic profile of elderly hypertensive patients and the relationship with the antihypertensive medication for a modern management of hypertension treatment. The Thoracic Electric Bioimpedance (TEB) is a noninvasive technology developed by HemoSapiens ${ }^{15,16}$, who allows standard evaluation of hemodynamic modulators and has demonstrated its usefulness and replicability in various populations ${ }^{17,18}$.

\section{MATERIALS AND METHODS}

Is a three months observational study on 150 elderly inpatients from a Romanian Geriatric Clinic, with hy- pertension diagnosis, in treatment of antihypertensive drugs classes: angiotensin-converting-enzyme-inhibitor [IECA], angiotensin-receptors-blockers [ARBs], beta blockers [BB], calcium-channel-antagonists [ACC], diuretics. Exclusion criteria were: (a) to have had a history of the following pathologies within the last 6 months: myocardial infarction, unstable angina pectoris, percutaneous coronary intervention, bypass surgery, congestive heart failure stage III-IV, hypertensive encephalopathy, stroke, or (b) conditions that could limit the bioimpedance method (obesity assessed by a $\mathrm{BMI}>40$, rhythm and conduction disturbances such as atrial fibrillation, left bundle block etc).

The final group included 44 hypertensive patients ( $72 \%$ females) with a mean age of $74.68 \pm 7.49$ years. We measured daily blood pressure and evaluated the hemodynamic profile using TEB (HOTMAN ${ }^{\circledR}$ System). In this regard, we evaluated the hemodynamic modulators (volemia, inotropy and vasoconstriction) and the hemodynamic status (mean blood pressure). All statistical analyses were done with IBM SPSS 20.0.

The study was approved by the Institutional Research Committee. Included inpatients agreed to participate in this study and signed the Informed Consent Form. All expenses were covered by the hospital. Patients received no financial incentives for their participation.

\section{RESULTS}

\section{Prevalence of antihypertensive medication in studied group}

The most used (60\%) antihypertensive drugs were $\mathrm{ACEI} / \mathrm{ARB}$ s (perindoprilum, ramiprilum, enalaprilum, candesartanum, telmisartanum) than while calcium-channel-antagonists (lercanidipinum, amlodipinum) represented only $22.7 \%$. Perindoprilum was the most used drug (36.7\%) from ACEI class, next to candesartanum (16.3\%) from ARBs used as monotherapy. Indapamidum was the leading class (85.7\%) from the patients under diuretics. Among beta blockers, carvedilolum was the most used drug (42.9\%). 


\section{Relationships between hemodynamic modulators and current therapy}

Approximately $79.5 \%$ of the patients had a controlled $\mathrm{BP}$, from which $93.1 \%$ present at least one altered modulator $(\mathrm{p}<0.0001)$. The distribution of altered modulators was: $72.7 \%$ hypervolemia, $52.3 \%$ hypoinotropy vs $40.9 \%$ hyperinotropy and $43.2 \%$ vasoconstriction vs $6.8 \%$ vasodilatation. Inotropism profile shows that using telmisartanum is the most balanced from ACEI/ ARBs classes, the rest of them determining hypoinotropy (Figure 1).

The treatment effect of beta blockers on chronotropism is different, depending on age and type of beta blockers used (selective/non-selective). Most patients (54.5\%) with controlled blood presure by beta blockers

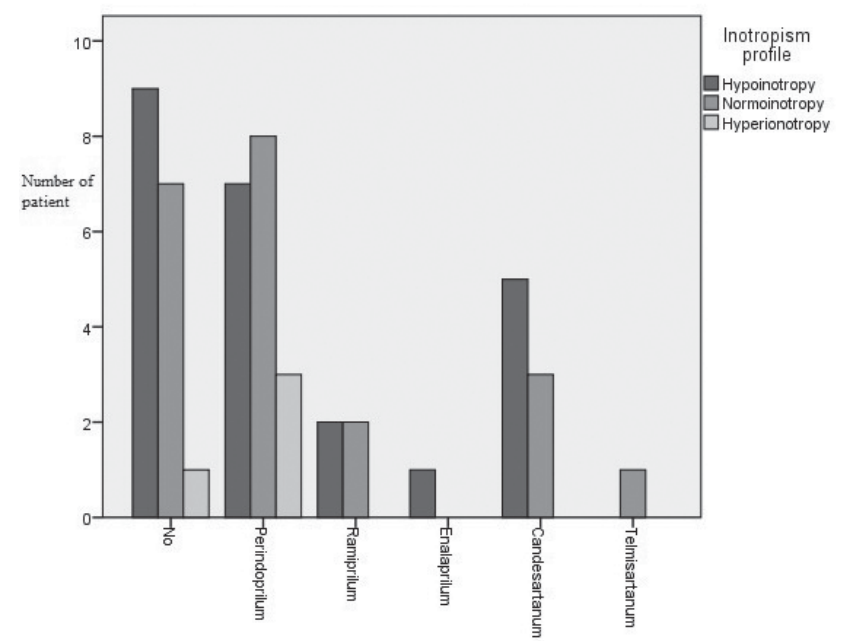

Figure 1. The distribution of patients after inotropism profile according to the ACEI/ARBs treatment. had semnificative statistic results for hipochronotropism $\left[\chi^{2}=11.35 ; \mathrm{p}=0.001\right]$ for adult inpatients $(42.9 \%)$ and very old age group (33.3\%) than metoprololum $(8.7 \%)$. The incidence of normochronotropism is semnificative observed at elderly and old age groups in treatment with carvedilolum $(25.0 \%$ respectively 26.1\%) (Table I.)

Patients included in the study had treatment with indapamide of fixed dose of $1.5 \mathrm{mg}$ daily and furosemide administered inconstant at a half dose than ESH/ ESC guidelines. Outcomes for volemia profile show: $65.5 \%$ of the the controlled blood pressure from which $29.7 \%$ with diuretics therapy group, reported hypervolemia $\left[\chi^{2}=2,79 ; p=0,095\right]$. Only the patients on indapamidum treatment have had more frequent hypovolemia comparative with those on furosemide treatment which had hypervolemia. Spironolactone and the combination of the diuretics are better for a normovolemic status (Figure 2).

\section{DISCUSSION}

The current state of knowledge of hypertension by age, sex and drugs interactions shows that in the absence of hemodynamic information, the clinician cannot assess the cause of lack of response among compliant patients. The hemodynamic management system helped identifying the causes of the lack of therapeutic control. Particularly in the elderly may not be beneficial to lower the SBP below $140 \mathrm{mmHg}$, so, the recommendations from the clinical trials should be approached with caution.

Different meta-analyses have shown that here is no clinically difference between beta-blockers and other

Table 1. The relationship between types of beta blockers and chronotropic profile by age groups

\begin{tabular}{|c|c|c|c|c|c|}
\hline \multirow[b]{2}{*}{ Age groups } & \multirow[b]{2}{*}{ BB treatment } & \multicolumn{4}{|c|}{ Chronotropism profile } \\
\hline & & Hypochronotropy & Normochronotropy & Hyperchronotropy & P value \\
\hline \multirow[t]{3}{*}{ Adult } & No Betablockers & $14.3 \%$ & $14.3 \%$ & $0.0 \%$ & 0.705 \\
\hline & Carvedilolum & $42.9 \%$ & $14.3 \%$ & $0.0 \%$ & 0.05 \\
\hline & Nebivololum & $14.3 \%$ & $0.0 \%$ & $0.0 \%$ & 0.9 \\
\hline \multirow[t]{3}{*}{ Elderly } & No Betablockers & $25.0 \%$ & $12.5 \%$ & $12.5 \%$ & 0.8 \\
\hline & Carvedilolum & $18.8 \%$ & $25.0 \%$ & $0.0 \%$ & 0.001 \\
\hline & Metoprololum & $0.0 \%$ & $6.3 \%$ & $0.0 \%$ & 0.3 \\
\hline \multirow[t]{3}{*}{ Old } & No Betablockers & $26.1 \%$ & $13.0 \%$ & $13.0 \%$ & 0.4 \\
\hline & Carvedilolum & $13.0 \%$ & $26.1 \%$ & $0.0 \%$ & 0.05 \\
\hline & Metoprololum & $8.7 \%$ & $0.0 \%$ & $0.0 \%$ & 0.7 \\
\hline \multirow[t]{3}{*}{ Very old } & No Betablockers & $0.0 \%$ & $33.3 \%$ & $0.0 \%$ & 0.6 \\
\hline & Carvedilolum & $33.3 \%$ & $0.0 \%$ & $0.0 \%$ & 0.01 \\
\hline & Metoprololum & $33.3 \%$ & $0.0 \%$ & $0.0 \%$ & 0.8 \\
\hline
\end{tabular}




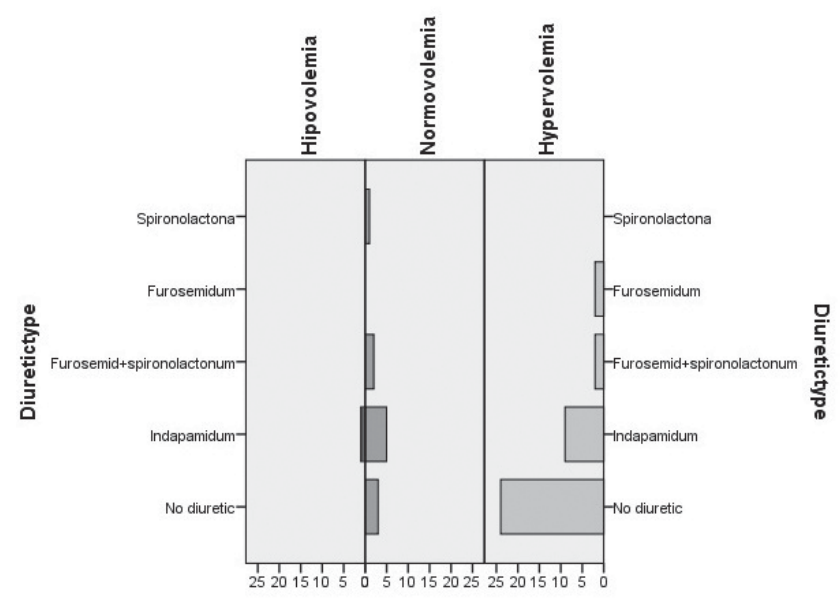

Figure 2. The distribution of patients after volemia profile according to the diuretic.

drug classes in decreasing high blood pressure at the elderly but the new beta-blockers, as nebivololum, carvedilolum and celiprololum, offer additional important advantages, compared with traditional $\beta$-blockers ${ }^{19}$. Our study shows that carvedilolum had an advantage in chronotropic profile. An observational study conducted in nine European Hypertension Excellence centers that evaluated 134 treated but uncontrolled hypertensive patients showed that almost of them (98.5\%) presented with altered hemodynamic modulators and that the hemodynamic profile was very heterogeno$\mathrm{us}^{20}$. This results are comparable to our study $(93.1 \%$ with at least one alterated hemodynamic modulator), but with a lower rate of hypervolemia $(72.2 \%)$ than that reported by Viigimaa et al. $(96.4 \%)^{11}$. A careful analysis of all hemodynamic modulators should precede pharmacological treatment, in order to achieve a normo-hemodynamic status. The potential clinical benefits of using cardiac impedance technique for the daily management of patients on a large-scale would require further testing of outcomes through longitudinal studies ${ }^{12,20}$ and of hemodynamic status among patients with unresponsive hypertension too. Antihypertensive therapy with diuretics is particularly effective when combined with reduced dietary sodium intake. The vast majority of hypertensive patients are treated with thiazide diuretics and one third of them have hypervolemia, as a consequence of under dosing the diuretics, compared with the recommended standards. Several randomized controlled trials of patients with systolic-diastolic hypertension in antihypertensive treatment showed that the most used line of therapy was a diuretic or a beta-blocker regardless of age group $^{21}$. Benetos et al. as a expert opinion of the management of hypertension in very old patients highlights that the treatment decisions in frail elderly patients must base on comorbidities and must carefully monitor the effects of treatment. Therapy with ARBs and ACEIs, particularly using brain-penetrating drugs such as captopril, perindopril and telmisartan appears to improve blood-brain barrier function, increase cerebral blood flow and reduce inflammation ${ }^{22}$. Long-term treatment with diuretics may also reduce the cardiac after load by promoting systemic vasodilatation, which can lead to improved ventricular ejection. Old and very old patients may have episodes of hypotension with the possibility of falls. This phenomenon could be avoided through knowledge/evaluation of hemodynamic status and changing their actual antihypertensive medication. Drug-drug and drug-disease interactions are common in older adults and may have a negative impact on health-related quality of life $3,4,5,23$.

For the future, after the new hypertension guideline by American College of Cardiology and American Hypertension Association, which eliminates the category of pre-hypertension, categorizing patients as having either Elevated (120-129 and less than 80) and stage I hypertension(130-139 or $80-89)^{24}$ we can have a new perspective. In this area we should also focus the future research on issues related to implementation of a risk-based approach to cardiovascular disease prevention, including the use of BP-lowering medications especial in elderly patients.

\section{CONCLUSIONS}

The majority of participants presented at least one altered hemodynamic modulator. Hemodynamic profile helps identify the causes of uncontrolled hypertension with different classes of antihypertensive drugs. Telmisartanum is more protective for inotropism and the effect of beta blockers on chronotropism is depending on age and type (selective/non-selective). The effect of thiazide diuretics, associated with a high risk of falls in the elderly, shows the presence of hypervolemia in a small rate, which implies individualized treatment at the elderly, depending on comorbidities and drug interactions.

\section{Compliance with ethics requirements:}

The authors declare no conflict of interest regarding this article.

The authors declare that all the procedures and experiments of this study respect the ethical standards in 
the Helsinki Declaration of 1975, as revised in 2008(5), as well as the national law. Informed consent was obtained from all the patients included in the study.

\section{References}

1. Kieldsen SE, Stenhjem A, Os I, Van de Borne P, Burnier M, Narkiewicz K, Redon J, Agabiti Rosei E, Mancia G. Treatment of high blood pressure in elderly and octogenarians: European Society of Hypertension statement on blood pressure targets. Blood Press 2016; 25(6):333-336.

2. Den Ouden MEM, Schuurmans MJ, Mueller-Schotte S, et al. Do subclinical vascular abnormalities precede impaired physical ability and ADL disability? Exp Gerontol. 2014; 58:1-7.

3. Capisizu A, Movileanu T, Aurelian S, Zamfirescu A, Vlad L, Dascalescu R. Evaluation of the hemodynamic profile in hospitalized hypertensive old age patients, using Hotman(R) integrated hemodynamic management system. Atherosclerosis 2014 ; 235,2, e263(abstract).

4. Cozlea DL, Farcas DM, Vari C, Keresztesi AA, Tifrea R, Cozlea L, Dogaru G. The efficiency of metoprolol tartrate in the treatment of pure arterial hypertension at patients with coronary artery disease and the risk factors associated. Farmacia 2013, 61(4)13724.

5. David Guay RP. The pharmacology of aging in Brocklehurst's Textbook of Geriatric Medicine and Gerontology (Seventh Edition), Ed. Springer 2011, 23:736-777.

6. McLean AJ, LeCouteur DG. Aging biology and geriatric clinical pharmacology. Pharmacol Rev 2004, 56:163-184.(13)

7. Schwartz JB: The current state of knowledge of age, sex, and their interactions on clinical pharmacology. Clin Pharmacol Ther 2007, 82:87-96.

8. Tinetti ME, Han L, Lee DSH, et al. Antihypertensive medications and serious fall injuries in a nationally representative sample of older adults. JAMA Intern Med 2014; 174:588-95).

9. Duprez DA. Systolic hypertension in the elderly: addressing an unmet need. Am J Med. 2008;121:179-84.e3

10. Smith R, Levy P, Ferrario C. Efficacy of noninvasive hemodynamic monitoring to target reduction of blood pressure levels (CONTROL). Am J Hypertens 2005, 18: 94 A.

11. Viigmaa M, Talvik A, Wojciechowska W, Kawecka-Jaszcz K, Toft I, Stergiou GS et al. Identification of the hemodynamic modulators and hemodynamic status in uncontrolled hypertensive patients. Blood Press 2013, 22(6):362- 70.

12. Bromfield SG, Bowling CB, Tanner RM, et al. Trends in hypertension prevalence, awareness, treatment, and control among US adults 80 years and older, 1988-2010. J Clin Hypertens (Greenwich). 2014;16:270-6

13. Grandison MK, Boudinot FK. Age-related changes in protein binding of drugs: implications for therapy. Clin Pharmacokinet, 2000, 38:271-290.
14. Taler SJ, Textor SC, Augustine JE. Resistant hypertension: Comparing hemodynamic management to specialist care. Hypertension 2002, 39: 982 - 988

15. Guidelines for the management of arterial hypertension. The Task Force for the management of arterial hypertension of the European Society of Hypertension (ESH) and of the European Society of Cardiology (ESC), Journal of Hypertension 2013 31:1281-1357.

16. HOTMAN System-integrated hemodynamic management system, Operator' s manual, Sedona, AZ: HEMO SAPIENS, 2011 2-20.

17. Faini A, Omboni S, Tifrea M, Bubenek S, Lazar O, Parati G. Cardiac index assessment: validation of a new non-invasive very low current thoracic bioimpedance device by thermodilution. Blood Press 2014, 23(2):102-8.

18. Parmar CV, Prajapati DL, Chavda VV, Gokhale PA, Mehta HB and Shah CJ. A Study of Cardiac Parameters using Impedance Plethysmography (IPG) in Healthy VolunteersJ. Phys. Pharm. Adv 2012, 2(10):365-379.

19. Herrera J. Beta-blockers use for hypertension in the elderly. Cardiovasc Hematol Agents Med Chem 2015;12(3):152-9.

20. Wolf-Maier K, Cooper RS, Kramer H, Banegas JR, Giampaoli S, Joffres MR et al. Hypertension treatment and control in five European countries, Canada and the United States. JAMA 2003 289:2363-2369.

21. Dyer AR, Stamler J, Shekelle RB, Schonberger JA, Farinaro E. Hypertension in the elderly. Med Clin North Am 1997:61:513529

22. Benetos A, Bulpitt CJ, Petrovic M, Ungar A, Agabiti Rosei E, Cherubini A, Redon J, Grodzicki T, Dominiczak A, Strandberg T, Mancia G. An expert opinion from the European Society of Hypertension-European Union Geriatric Medicine Society Working Group on the Management of Hypertension in Very Old, Frail Subjects. Hypertesnion 2016;67:820-825

23. Tautau O, Antoji I, Macovei V, Popescu EC, Stoica A, Selaru D, Matura D, Dorobantu M. Blood Pressure Control and Quality of Life in Hypertensive Patients Treated with Amlodipine/Valsartan Fixed Dose Combination - IMPROVE Study Results. Modern Medicine, 2016, vol 23, no 2: 135-142.

24. Whelton PK, Carey RM, Aronow WS, Casey Jr DE, Collins KJ, Dennison Himmelfarb C, DePalma SM, Gidding S, Jamerson KA, Jones DW, MacLaughlin EJ, Muntner P, Ovbiagele B, Smith Jr SC, Spencer CC, Stafford RS, Taler SJ, Thomas RJ, Williams Sr KA, Williamson JD, Wright Jr JT, 2017 ACC/AHA/AAPA/ABC/ ACPM/AGS/APhA/ASH/ASPC/NMA/PCNA Guideline for the Prevention, Detection, Evaluation, and Management of High Blood Pressure in Adults, Journal of the American College of Cardiology (2017), doi: 10.1016/j.jacc.2017.11.006 
